NOTAS

\title{
HOMENAJE A IGNACIO PADILLA
}

La revista Estudios, del Departamento Académico de Estudios Generales, se une en este número a los homenajes que se han rendido al escritor mexicano Ignacio Padilla, a casi dos años de su trágico deceso.

Ignacio Padilla, Nacho, como le decían sus amigos, o el "físico cuéntico", como él se denominaba, fue el escritor más brillante y creativo de la generación del crack, junto con su compañero de aventuras literarias Jorge Volpi.

Los textos que se muestran a continuación, de Alejandro Higashi, Gabriel Astey y Danaé Torres de la Rosa, nos brindan la oportunidad de conocer su obra y su trayectoria. Fueron presentados durante su homenaje en la Semana Estudios 2017. Estudios agradece a Gabriel Astey la coordinación de este encuentro. 
CITAM Derechos Reservados.

La reproducción total o parcial de este artículo se podrá hacer si el ITAM otorga la autorización previamente por escrito. 